\title{
Model Pendidikan Anti Korupsi di Sekolah Dasar dalam Mewujudkan Generasi Yang Bersih dan Berintegritas Sejak Dini
}

\author{
Nuzus Sakinah ${ }^{1}$, Nuhasanah Bakhtiar ${ }^{2}$ \\ 1,2Program Magister Pendidikan Guru Madrasah Ibtidaiyah, Universitas Islam Negeri Sultan Syarif Kasim Riau \\ e-mail:_nuzussakina@gmail.com
}

ABSTRACT. Indonesia is the most corrupt country among 12 Asian countries. so that prevention aspects in the form of Anti-Corruption Education (PAK) need to be implemented. The purpose of this study is to explore the Anti-Corruption Education model in elementary schools in realizing a generation that is clean and has integrity. This research is a library research or library research which aims to study text, books, and publication texts regarding content analysis models, namely the application of Anti-Corruption Education. As well as the results expected in this study the first presentation about the meaning of corruption, features of corruption, forms of corruption, causes of corruption and the impact of corruption. Second, bolding a film screening about corruption and the latter using an anti-corruption education model to be implemented for early childhood.

Keywords: PAK values, anti-corruption education, PAK model.

\section{PENDAHULUAN}

Berbagai macam persoalan terkait korupsi dianggap sebagai hal yang biasa, karena seringkali persoalan itu muncul di berbagai media masa dan tidak ada ujung penyelesaiannya. Parahnya lagi, penanganan serta hukuman bagi koruptor tidak membuat jera seseorang untuk melakukan tindakan yang sama. Akibatnya adalah semakin merebaknya para koruptor yang bermunculan di negeri ini (Ma'as Shoirin,108). Kata korupsi berasal dari bahasa Latin "corruputio" atau "corruptus" yang berarti kerusakan atau kebobrokan (Samidan, 2011). Arti kata korupsi secara harfiah adalah kebusukan, keburukan, kebejatan, ketidakjujuran, dapat disuap, tidak bermoral, penyimpangan dari kesucian (Karsona, 2013). Istilah korupsi dapat pula mengacu pada pemakaian dana pemerintah untuk tujuan pribadi. Defenisi ini tidak hanya menyangkut korupsi moneter yang konvensional, akan tetapi menyangkut pula korupsi politik dan administratif. Seorang administrator yang memanfaatkan kedudukannya untuk menguras pembayaran tidak resmi dari para investor (domestic maupun asing), memakai sumber pemerintah, kedudukan, martabat, status, atau kewenangannya yang resmi, untuk keuntungan pribadi dapat pula dikategorikan melakukan tindak korupsi ( Marni Anastasia Tamba, 2017: 513). Ada beberapa jurnal yang terbit tentang korupsi diantaranya yang ditulis oleh Miswanto, dkk "Aplikasi Pembelajaran Anti Korupsi bagi Anak Remaja Berbasis Android" dan selanjutnya jurnal yang ditulis oleh Andreas James Darmawan dan Nunun Bonafix "Perancangan Komunikasi Visual Web Games Interaktif "Gooclean.com" Guna 
Mananamkan Budaya Anti Korupsi Sejak Dini”. Sementara yang ingin dibahas oleh penulis sendiri yaitu tentang "Model Pendidikan Anti Korupsi di Sekolah Dasar dalam Mewujudkan Generasi yang Bersih dan Berintegritas Sejak Dini”. Dengan adanya model pembelajaran diharapkan seorang guru mampu mengaplikasikannya dengan baik agar tercipta generasi yang bersih dan berintegritas sejak dini.

Setiap hari diberbagai media masyarakat disuguhi dengan berbagai informasi perilaku korupsi yang merugikan keuangan negara. Meningkatnya kasus korupsi di negeri ini dapat dilihat dari data penanganan perkara tindak pidana korupsi oleh Komisi Pemberantasan Korupsi (KPK) dari tahun 2004-2014: penyelidikan 596 perkara, penyidikan 363 perkara, penuntutan 287 perkara, inkracht 243 perkara, dan eksekusi 252 perkara. Data terakhir yang dipublikasikan oleh Indonesian Corrupsion Watch (ICW) sampai awal 2015 jumlah kasus melonjak menjadi 2.433, dari jumlah itu 536 proses penyidikan oleh Kepolisian, 1.775 oleh Kejaksaan dan 122 oleh KPK (Komisi Pemberantasan Korupsi, 2014).

Rentetan kasus korupsi yang dilakukan oleh sejumlah pejabat publik di Indonesia membuktikan bahwa upaya pemberantasan korupsi belum berjalan optimal. Oleh karena itu, upaya pemberantasan korupsi tidak bisa sepenuhnya diserahkan kepada pihak berwajib. Kita semua, khususnya yang bergerak dalam bidang pendidikan wajib turut serta dalam upaya pemberantasan virus masyarakat ini. Seperti sistem pendidikan anti korupsi yang berisi tentang sosialisasi bentuk-bentuk korupsi, cara pencegahan dan pelaporan serta pengawasan terhadap tindak pidana korupsi yang dapat dilaksanakan di setiap jenjang pendidikan. Selain mengadakan sosialisasi sikap anti korupsi bisa diberikan kepada anak melalui aplikasi yang bisa didownload di playstore anak bisa memperoleh informasi baik secara langsung maupun tidak langsung mengenai suatu hal atau masalah. Hal ini agar kita tidak tertinggal isu atau informasi yang saat ini sedang berkembang.

Pendidikan anti korupsi harus ditanamkan secara terpadu mulai dari pendidikan dasar sampai perguruan tinggi. Pendidikan anti korupsi ini akan berpengaruh pada perkembangan psikologis siswa. Diharapkan melalui pendidikan mengenai anti korupsi sejak dini dapat menciptakan anak yang memiliki kepribadian lebih mawas diri, sehingga ketika saatnya terjun ke masyarakat, anak tidak lagi mudah terpengauh dan memiliki pengetahuan yang cukup dan benar mengenai anti korupsi. Setidaknya terdapat dua tujuan yang ingin dicapai dari pendidikan anti korupsi ini. Pertama untuk menanamkan semangat anti korupsi pada setiap anak bangsa. Melalui pendidikan ini, diharapkan semangat anti korupsi akan mengalir di dalam darah setiap generasi dan tercermin dalam perbuatan sehari-hari. Jika korupsi sudah diminimalisir, maka setiap pekerjaan membangun bangsa akan maksimal. Kedua adalah, menyadari bahwa pemberantasan korupsi bukan hanya tanggung jawab lembaga penegak hukum seperti KPK, Kepolisian dan Kejaksaan Agung, melainkan menjadi tanggung jawab setiap anak bangsa. (Eko Handoyo, Martien Herna Susanti, 2014).

Media yang paling ampuh untuk mengubah mentalitas bangsa adalah lewat pendidikan dan keyakinan agama. Pendidikan yang mampu mengubah mentalitas adalah pendidikan yang dilaksanakan dengan sungguh-sungguh dan sepenuh hati, bukan hanya sekadar formalitas atau kepura-puraan. Dunia pendidikan harus mengakui begitu pentingnya dan perlunya kembali kepada pendidikan moral yang dikerucutkan kepada pendidikan anti korupsi di sekolah untuk membentuk watak dan kepribadian siswa sehingga mereka menjadi manusia dewasa yang bertanggung jawab dalam kehidupan 
masyarakat ( Rosida Tiurma manurung, 2012: 234). PAK dalam dunia pendidikan sangat perlu adanya, jadi sebenarnya nilai-nilai PAK menjadi tanggung jawab semua pendidik, betapa pentingnya peran pendidik yaitu guru, dalam menanamkan nilai-nilai moral seperti kejujuran, sehingga benih-benih korupsi tidak muncul, karena tanpa disadari dari kecurangan-kecurangan yang terjadi dalam proses pembelajaran di sekolah, dapat menanamkan nilai-nilai koruptif pada para siswa (Anom wahyo Asmorojati, 2017: 491).

Selain itu, pendidikan anti korupsi sangat penting diberikan oleh guru agar siswa mengenal lebih dini hal-hal yang berkenaan dengan korupsi, sehingga terciptanya generasi muda yang dengan sadar dan memahami bahaya korupsi, bentuk-bentuk korupsi, dan juga mengetahui sanksi-sanksi yang akan diterima jika seseorang melakukan korupsi. Jika anak telah diberikan pendidikan tentang nilai-nilai PAK diharapkan anak bisa menjadi generasi muda yang bermoral baik serta membangun karakter teladan agar anak tidak melakukan korupsi dini. Jadi, semua guru yang ada di sekolah harus menanamkan nilai-nilai yang diajarkan dalam PAK seperti mengajarkan kepada anak-anak nilai kejujuran, kepedulian, kedisiplinan, tanggung jawab, kerja keras, kesederhanaan, keberanian dan kepedulian. Contohnya guru di sekolah adanya warung kejujuran dengan adanya warung kejujuran ini akan memberikan manfaat yang baik kepada siswa, guru maupun sekolah ini berguna untuk melatih dan membiasakan kejujuran serta tanggung jawab. (Eko Handoyo, Martien Herna Susanti, 2014).

\section{METODOLOGI}

Jenis penelitian ini adalah penelitian kepustakaan atau library research. Penelitian ini bertujuan untuk mengkaji teks, buku-buku, dan naskah publikasi mengenai pandangan potensi penerapan Pendidikan Anti Korupsi (PAK) dalam kurikulum atau pembelajaran di sekolah yang bersumber dari naskah-naskah kepustakaan relevan yang diangkat sebagai permasalahan dalam topik penelitian ini. Sumber data yang digunakan adalah data-data hasil penelitian terdahulu yang relevan Langkah-langkah yang dilakukan diantaranya pengumpulan data pustaka, membaca, mencatat, serta membandingkan literatur untuk kemudian diolah dan menghasilkan kesimpulan. Data yang digunakan merupakan data sekunder yang berasal dari textbook, jurnal, artikel ilmiah, dan literature review yang berisikan tentang konsep yang sedang dikaji. Penelitian ini merupakan penelitian analisis kebutuhan yang nantinya digunakan sebagai dasar dalam merancang model dan metode yang sesuai untuk mengajarkan PAK di sekolah.

\section{HASIL DAN PEMBAHASAN}

\section{Pentingnya PAK di Sekolah}

Pendidikan anti korupsi sangat penting untuk diaplikasikan kepada anak sejak usia dini. Dalam mengatasi masalah ini, pemerintah melalui berbagai kebijakan berupa peraturan perundang-undangan dari yang tertinggi yaitu Undang-Undang Dasar 1945 sampai dengan Undang-Undang tentang Komisi Pemberantasan Tindak Pidana Korupsi berupaya untuk dapat memberantas korupsi. Sebagaimana instruksi Presiden SBY yang disampaikan saat peresmian gedung Majelis Tafsir Al-Qur'an di Solo, tanggal 8 Maret 2009. Dalam pidato resminya tersebut, Presiden SBY mengajak bangsa Indonesia berjihad melawan korupsi. Meminta siapapun yang memiliki kekuasaan di eksekutif dan legislatif untuk mencari rezeki dengan halal dan tidak menyalahgunakan kekuasaan (Kompas, 2012). 
Sejak didirikannya Komisi Pemberantaan Korupsi (KPK) sebagai Lembaga Independen Pemberantasan Tindak Pidana Korupsi, sepak terjang pemberantasan korupsi di Indonesia mengalami perubahan yang signifikan ke arah yang lebih baik. (Miswanto, 2016). Meskipun telah dilakukan berbagai upaya, Indonesia kembali dinilai sebagai negara paling terkorup di Asia pada awal tahun 2004 dan 2005 berdasarkan hasil survei dikalangan para pengusaha dan pebisnis oleh lembaga konsultan Political and Economic Risk Consultancy (PERC). Hasil survei lembaga konsultan PERC yang berbasis di Hong Kong menyatakan bahwa Indonesia merupakan negara yang paling korup di antara 12 negara Asia. Predikat negara terkorup diberikan karena nilai Indonesia hampir menyentuh angka mutlak 10 dengan skor 9,25 (nilai 10 merupakan nilai tertinggi atau terkorup). Pada tahun 2005, Indonesia masih termasuk dalam tiga teratas negara terkorup di Asia (Liputan 6.com, dalam Siswanto, dkk : 2017).

Sejauh ini permasalahan korupsi menjadi topik yang belum bisa diselesaikan oleh pemerintah karena masih banyaknya pemberitaan di media-media sosial tetang korupsi. Maka dengan itu pendidikan anti korupsi ini sangat penting disampaikan oleh pendidik. Melalui Pendidikan Anti Korupsi diharapkan bisa mewujudkan generasi muda yang jujur dan berintegritasi sejak usia dini. Peran Pendidikan dalam pencegahan tindak korupsi sangat tepat diintegrasikan dalam domain kognitif (pengetahuan) afektif (sikap) dan psikomotor (keterampilan). Ada delapan belas karakter yang harus dimiliki oleh peserta didik, yakni cinta damai, peduli sosial, tanggung jawab, jujur, toleransi, disiplin, kerja keras, kreatif, mandiri, demokrasi, rasa ingin tahu, dan semangat kebangsaan. Karakter-karakter tersebut merupakan kekuatan yang dapat dikembangkan dalam diri siswa untuk meredam potensi tumbuhnya korupsi. Karakter anti korupsi tersebut dikembangkan sejalan dengan rumusan tujuan pendidikan karakter, yakni menanamkan kebiasaan (babituation) tentang hal mana yang baik sehingga peserta didik menjadi paham tentang mana yang benar dan salah, mampu merasakan nilai yang baik, serta biasa melakukannya. Pendidikan karakter (karakter anti korupsi) yang baik harus melibatkan bukan saja aspek moral knowing, akan tetapi juga loving good (moral feeling), dan moral action (Lickona, 1996).

Setidaknya terdapat dua tujuan yang ingin dicapai dari pendidikan anti korupsi ini. Pertama untuk menanamkan semangat anti korupsi pada setiap anak bangsa. Melalui pendidikan ini, diharapkan semangat anti korupsi akan mengalir di dalam darah setiap generasi dan tercermin dalam perbuatan sehari-hari. Jika korupsi sudah diminimalisir, maka setiap pekerjaan membangun bangsa akan maksimal. Kedua adalah, menyadari bahwa pemberantasan korupsi bukan hanya tanggung jawab lembaga penegak hukum seperti KPK, Kepolisian dan Kejaksaan agung, melainkan menjadi tanggung jawab setiap anak bangsa.

\section{Nilai-Nilai Pendidikan Anti Korupsi}

Mengelompokkan hasil identifikasi setiap aspek PAK yang saling terkait. Setelah melakukan inventarisasi aspek potensi PAK dari sisi kelebihan dan kekurangan jika PAK masuk dan diterapkan di sekolah, yaitu PAK sangat perlu dimasukkan dalam pendidikan baik itu pendidikan formal maupun non formal. Dengan adanya pendidikan anti korupsi ini kita bisa menanamkan nilai-nilai anti korupsi kepada siswa, dengan diterapkannya di sekolah ini akan melatih anak atau mencegah anak untuk melakukan korupsi dini, pendidikan anti korupsi ini harus sudah ada dari anak sekolah dasar hingga perguruan tinggi, nilai-nilai anti korupsi ini diajarkan dengan harapan agar terciptanya generasi muda yang bermoral dan berintegrasi yang tinggi. 
Berikut merupakan nilai-nilai antikorupsi yang perlu ditanamkan pada diri siswa (Ma'as Shobirin : 110).

\begin{tabular}{|c|c|c|}
\hline No & Nilai & Indikator \\
\hline 1 & Jujur & $\begin{array}{l}\text { - Selalu berbicara dan berbuat sesuai dengan } \\
\text { fakta (konsisten) } \\
\text { - Tidak melakukan perbuatan curang } \\
\text { - Tidak berbohong } \\
\text { - Tidak mengakui milik orang lain sebagai } \\
\text { miliknya. }\end{array}$ \\
\hline 2 & Disiplin & $\begin{array}{l}\text { Berkomitmen untuk selalu berperilaku } \\
\text { konsisten dan berpegang teguh pada aturan } \\
\text { yang ada dalam semua kegiatan }\end{array}$ \\
\hline 3 & Tanggung Jawab & $\begin{array}{l}\text { - Selalu menyelesaikan pekerjaan atau tugas-tugas } \\
\text { secara tuntas dengan hasil terbaik }\end{array}$ \\
\hline 4 & Kerja Keras & $\begin{array}{l}\text { - Selalu berupaya untuk menuntaskan suatu } \\
\text { pekerjaan dengan hasil yang terbaik } \\
\text { - Terhindari perilaku instan (jalan pintas) yang } \\
\text { mengarah pada kecurangan }\end{array}$ \\
\hline 5 & Sederhana & $\begin{array}{l}\text { Selalu berpenampilan apa adanya, tidak } \\
\text { berlebihan, tidak pamer dan tidak ria }\end{array}$ \\
\hline 6 & Mandiri & $\begin{array}{l}\text { - Selalu menuntaskan pekerjaan tanpa } \\
\text { mengandalkan bantuan dari orang lain } \\
\text { - Tidak menyuruh atau menggunakan } \\
\text { kewenangannya untuk menyuruh orang lain } \\
\text { untuk sesuatu yang mampu dikerjakan sendiri }\end{array}$ \\
\hline 7 & Adil & $\begin{array}{l}\text { - Selalu menghargai perbedaan } \\
\text { - Tidak pilih kasih }\end{array}$ \\
\hline 8 & Berani & $\begin{array}{l}\text { - Berani jujur } \\
\text { - Berani menolak ajakan untuk berbuat curang } \\
\text { - Berani melaporkan adanya kecurangan } \\
\text { - Berani mengakui kesalahan }\end{array}$ \\
\hline 9 & Peduli & $\begin{array}{l}\text { - Menjaga diri dan lingkungan agar tetap } \\
\text { konsisten dengan aturan yang berlaku } \\
\text { - Selalu berusaha untuk menjadi teladan dalam } \\
\text { menegakkan disiplin, kejujuran, dan tanggung } \\
\text { jawab }\end{array}$ \\
\hline
\end{tabular}

Metode yang cocok untuk PAK untuk mengembangkan kompetensi dasar siswa agar memiliki integritas yang tinggi

Metode yang cocok digunakan dalam pendidikan anti korupsi Elwina dan Riyanto (2008) menyarankan bahwa dalam menanamkan nilai-nilai anti korupsi sebaiknya menggunaka metode demokratis, pencarian bersama, metode keteladanan, dan live in.

\section{Metode Demokrasi}

Menekankan pencarian secara bebas dan penghayatan nilai-nilai hidup dengan langsung melibatkan anak untuk menanamkan nilai-nilai tersebut dalam pendampingan dan pengarahan guru. Anak diberi kesempatan untuk memberikan tanggapan, pendapat, dan 
penilaian terhadap nilai-nilai yang ditemukan. Guru tidak bersikap sebagai pemberi informasi satu-satunya dalam menemukan nilai-nilai anti korupsi yang dihayatinya. Guru berperan sebagai penjaga garis atau koridor dalam penemuan nilai hidup tersebut. Metode ini dapat digunakan untuk menanamkan nilai-nilai diantaranya keterbukaan, kejujuran, penghargaan pada pendapat orang lain, sportivitas, kerendahan hati dan toleransi. Melalui metode ini anak diajak untuk mulai berani mengungkapkan gagasan, pendapat, maupun perasaannya. Tahap demi tahap anak diarahkan untuk menata jalan pikiran, cara berbicara, dan sikap hidupnya. Dengan cara ini anak diajak untuk belajar menentukan nilai hidup secara benar dan jujur.

\section{Metode Pencarian Bersama}

Metode ini menekankan dalam pencarian bersama yang melibatkan siswa dan guru. Pencarian bersama lebih berorientasi pada diskusi atas soal-soal yang aktual dalam masyarakat, dimana proses ini diharapkan menumbuhkan sikap berpikir logis, analitis, sistematis, argumentatif untuk dapat mengambil nilai-nilai hidup dari masalah yang diolah bersama. Melalui metode ini siswa diajak aktif mencari dan menemukan tema yang sedang berkembang dan menjadi perhatian bersama. Dengan menemukan permasalahan, mengkritisi dan mengolahnya, anak diharapkan dapat mengambil nilai-nilai yang ada dan menerapkannya dalam kehidupan mereka. Dengan demikian anak akan aktif sejak dalam proses pencarian tema atau permasalahan yang muncul dalam pendampingan guru. Selain menemukan nilai-nilai dari permasalahan yang diolah, anak juga diajak untuk secara kritis analitis mengolah sebab akibat dari permasalahan yang muncul tersebut. Anak diajak untuk tidak cepat menyimpulkan apalagi mengambil sikap, namun dengan cermat dan hati-hati melihat duduk permasalahan untuk sampai pada pengambilan sikap. Anak diajak untuk melihat realita tidak hanya hitam-putih, tetapi lebih luas lagi yaitu adanya kemungkinan realita abu-abu.

\section{Metode Keteladanan}

Dalam dunia pendidikan apa yang terjadi dan tertangkap oleh anak bisa tanpa disaring akan langsung dilakukan. Proses kepribadian akan berlangsung kepada anak melihat orang yang diteladani. Guru dapat menjadi tokoh idola dan panutan bagi anak. Dengan keteladanan guru dapat membimbing anak untuk membentuk sikap yang kokoh. Keselarasan antara kata dan tindakan dari guru akan amat berarti bagi seorang anak, demikian pula apabila terjadi ketidakcocokan antara kata dan tindakan guru maka perilaku anak juga akan tidak benar. Dalam hal ini guru dituntut memiliki ketulusan, keteguhan, kekonsistenan hidup.

Proses penanaman nilai-nilai anti korupsi kepada anak melalui proses keteladanan pada mulanya dilakukan secara mencontoh, namun anak perlu diberi pemahaman mengapa hal itu dilakukan (Sanjaya, 2006). Misalnya, guru perlu menjelaskan mengapa kita tidak boleh korupsi, menjelaskan bahaya dari tindakan korupsi atau mengapa kita harus jujur, tidak mencontek pada waktu ulangan. Hal ini diperlukan agar sikap tertentu yang muncul benar-benar didasari oleh suatu keyakinan kebenaran sebagai suatu sistem nilai.

\section{Metode Live In}

Agar anak mempunyai pengalaman hidup bersama orang langsung dengan situasi yang sangat berbeda dengan kehidupan sehari-harinya. Dengan pengalaman langsung anak dapat mengenal lingkungan hidup yang berbeda dalam cara berpikir, tantangan, permasalahan, termasuk tentang nilai-nilai hidupnya. Kegiatan ini dapat dilaksanakan 
secara periodik. Dengan cara ini anak diajak untuk mensyukuri hidupnya yang jauh lebih baik dari orang lain, tumbuh sikap toleran dan sosial yang lebih tinggi pada kehidupan bersama. Anak perlu mendapat bimbingan untuk merefleksikan pengalaman tersebut, baik secara rasional intelektual maupun dari segi batin rohaninya. Hal ini perlu dijaga jangan sampai anak menanggapi pengalaman ini berlebihan, tetapi haruslah secara wajar dan seimbang.

Sumber belajar yang cocok untuk mendukung kegiatan pembelajaran PAK adalah lingkungan alamiah dan sosial-budaya, buku-buku pelajaran dan buku teks, audio visual, dan internet

Sumber belajar yang cocok mendukung kegiatan PAK sebagai berikut:

1 Lingkungan alamiah: penggunaan lingkungan memungkinkan terjadinya proses belajar yang lebih bermakna sebab anak dihadapkan pada situasi yang sebenarnya,

2 Buku dan buku teks : melalui buku guru bisa mengajarkan kepada anak tentang nilai-nilai anti korupsi selain itu anak juga bisa membaca tentang hal-hal yang berkenaan dengan pendidikan anti korupsi,

3 Audio visual: audio visual media yang mempunyai unsur suara dan gambar penggunaan audio visual ini akan menarik anak-anak untuk belajar,

4 Internet : penggunaan internet juga akan memudahkan guru dalam mengajar kerena informasinya update.

Sistem penilaian yang cocok untuk PAK untuk mengembangkan kompetensi dasar siswa adalah penilaian non tes (kinerja, sikap, portofolio, produk) dan penilaian dengan tes

1 Kinerja: hasil atau tingkat keberhasilan seseorang secara keseluruhan selama periode tertentu dalam melaksanakan tugas,

2. Sikap: sikap itu adalah reaksi atau tindakan perilaku,

3 Portofolio: laporan lengkap berupa dokumen atau informasi dari seseorang dalam mencapai tujuan yang telah ditetapkan,

4 Produk: sesuatu yang bisa dihasilkan contohnya seperti barang.

Model konseptual pembelajaran PAK meliputi lima tahapan yaitu: (1) kegiatan awal, (2) eksplorasi (penyelidikan dari berbagai perspektif), (3) elaborasi, 4) konfirmasi, dan (5) kegiatan akhir

Dalam penelitian ini yang telah dijalankan oleh peneliti, maka pengkaji dapat merumuskan fase-fase beserta aktivitas-aktivitas dalam melaksanakan proses pengajaran dan pembelajaran secara efektif dan efesien. Dalam tabel ini pengkaji menjelaskan setiap fase-fase dan tujuan, aktivitas pembelajaran serta contoh dari setiap aktivitas tersebut pada tabel 1 berkaitan dengan model konseptual dalam pelaksanaan proses pengajaran dan pembelajaran PAK di sekolah; 


\section{Tabel 1. Model konseptual dalam pelaksanaan proses pengajaran dan pembelajaran PAK}

\begin{tabular}{|c|c|c|c|}
\hline Fase & Tujuan & $\begin{array}{l}\quad \text { Aktivitas } \\
\text { pengajaran } \\
\text { pembelajaran }\end{array}$ & Contoh aktivitas \\
\hline $\begin{array}{c}\text { (1) } \\
\text { kegiatan awal }\end{array}$ & $\begin{array}{l}\text { Mempers } \\
\text { iapkan tujuan } \\
\text { dan } \\
\text { mempersiapkan } \\
\text { siswa }\end{array}$ & \begin{tabular}{l}
\multicolumn{1}{c}{ Guru } \\
menjelaskan tujuan \\
pembelajaran, \\
informasi, pentingnya \\
pelajaran, ran \\
mempersiapkan siswa \\
untuk belajar
\end{tabular} & $\begin{array}{l}\text { Guru menyampaikan } \\
\text { nilai-nilai anti korupsi, } \\
\text { (kejujuran, kepedulian, } \\
\text { kemandirian, kedisiplinan, } \\
\text { tanggung jawab, kerja } \\
\text { keras, kesederhanaan, } \\
\text { keberanian, keadilan. }\end{array}$ \\
\hline \multirow[t]{2}{*}{$\begin{array}{l}\text { (2) } \\
\text { eksplorasi } \\
\text { (penyelidikan } \\
\text { dari berbagai } \\
\text { perspektif), }\end{array}$} & $\begin{array}{l}\text { Mewujud } \\
\text { kan dan } \\
\text { menarik minat } \\
\text { siswa, dan } \\
\text { memotivasikan } \\
\text { pelajaran }\end{array}$ & \begin{tabular}{l}
\multicolumn{3}{c}{ (Mengklarifikasi } \\
(menemui) kunci fakta \\
yang harus diketahui, \\
mengkontektualisasikan \\
(memahami) masalah \\
korupsi di Indonesia \\
serta mendefenisikan \\
makna korupsi
\end{tabular} & $\begin{array}{l}\text { Temui Masalah: } \\
\text { Guru meminta siswa } \\
\text { untuk mencari sebuah } \\
\text { masalah tentang kasus } \\
\text { korupsi di Indonesia } \\
\text { Pahami Masalah: } \\
\text { Guru meminta siswa } \\
\text { untuk memahami } \\
\text { (mengkontekstualisasikan) } \\
\text { masalah korupsi Indonesia } \\
\text { Artikan Masalah } \\
\text { Guru meminta siswa } \\
\text { untuk fokus dalam satu } \\
\text { masalah dan mencoba } \\
\text { mendifinisikan inti dari } \\
\text { korupsi yang terjadi di } \\
\text { Indonesia }\end{array}$ \\
\hline & $\begin{array}{l}\text { Mengenal } \\
\text { idea yang sudah } \\
\text { ada dan } \\
\text { pemahaman } \\
\text { siswa } \\
\text { sebelumnya }\end{array}$ & \begin{tabular}{l}
\multicolumn{3}{c}{ Mengumpulkan } \\
semua ide atau \\
penjelasan \\
respon dan contoh \\
daripada relasi atau \\
pengelaman \\
(menjelajahi).
\end{tabular} & $\begin{array}{l}\text { Temui Ide } \\
\text { Guru meminta siswa } \\
\text { untuk mengumpulkan } \\
\text { semua ide baik tentang } \\
\text { bagaimana menanamkan } \\
\text { nilai-nilai anti korupsi } \\
\text { Berikan Penjelasan } \\
\text { Guru meminta siswa } \\
\text { untuk merespon dan } \\
\text { memberikan gambaran } \\
\text { atau contoh tentang } \\
\text { penanaman nilai-nilai anti } \\
\text { korupsi yang bisa } \\
\text { dilaksanakan di sekolah }\end{array}$ \\
\hline $\begin{array}{r}(3) \\
\text { elaborasi }\end{array}$ & \begin{tabular}{l}
\multicolumn{1}{c}{ Idea } \\
terdahulu \\
dikembangkan \\
dan disesuaikan
\end{tabular} & $\begin{array}{l}\text { Berdiskusi tentang } \\
\text { menanamkan nilai-nilai } \\
\text { anti korupsi di sekolab } \\
\text { selanjutnyarana siswa } \\
\text { menyimpulkan apa yang } \\
\text { telab diketahuinya }\end{array}$ & $\begin{array}{l}\text { Diskusi } \\
\text { Guru meminta siswa } \\
\text { untuk berdiskusi cara } \\
\text { menanamkan nilai-nilai } \\
\text { anti korupsi di sekolah dan } \\
\text { menyampaikan ide-ide }\end{array}$ \\
\hline
\end{tabular}




\begin{tabular}{|c|c|c|c|}
\hline & & & $\begin{array}{l}\text { yang mereka peroleh } \\
\text { sintesis } \\
\text { Guru meminta siswa } \\
\text { untuk menyimpulkan } \\
\text { semua idea baik menjadi } \\
\text { idea yang terbaik secara } \\
\text { individu maupun } \\
\text { kumpulan bagaimana cara } \\
\text { menanamkan nilai-nilai } \\
\text { anti korupsi di sekolah }\end{array}$ \\
\hline & $\begin{array}{l}\text { Menyeles } \\
\text { aikan masalah, } \\
\text { melakukan } \\
\text { penelitian } \\
\text { dengan } \\
\text { pengamatan } \\
\text { Mengapli } \\
\text { kasikan idea } \\
\text { dalam situasi } \\
\text { yang baru dan } \\
\text { berbeda }\end{array}$ & $\begin{array}{l}\text { Menyampaikan } \\
\text { ide-ide bagaimana } \\
\text { menanamkan nilai-nilai } \\
\text { anti korupsi di sekolah }\end{array}$ & \begin{tabular}{l} 
Menyusun Idea \\
penyelesaian masalah \\
\multicolumn{1}{c}{ Guru meminta siswa } \\
untuk menyimpulkan \\
semua idea baik menjadi \\
idea yang terbaik secara \\
individu \\
kumpulan maupun \\
menanamkan nilai-nilai \\
anti korupsi di sekolah.
\end{tabular} \\
\hline $\begin{array}{c}\text { (4) } \\
\text { konfirmasi, }\end{array}$ & $\begin{array}{l}\text { Mengeta } \\
\text { hui sejauh } \\
\text { mana idea } \\
\text { sudah } \\
\text { mengalami } \\
\text { perubahan }\end{array}$ & $\begin{array}{l}\text { Menyimpulkan } \\
\text { pembelajaran yang } \\
\text { berbubungan dengan } \\
\text { penanaman nilai-nilai anti } \\
\text { korupsi }\end{array}$ & $\begin{array}{l}\text { Membangun } \\
\text { pengetahuan yang telah } \\
\text { dirancang } \\
\text { Guru meminta siswa } \\
\text { untuk membangun } \\
\text { pengetahuan yang telah } \\
\text { dirancang secara individu } \\
\text { maupun kumpulan agar } \\
\text { terlaksananya nilai-nilai } \\
\text { anti korupsi agar terlaksana } \\
\text { di sekolah dengan baik } \\
\text { Tindakan } \\
\text { Profesional } \\
\text { Guru meminta siswa } \\
\text { untuk menerapkan nilai- } \\
\text { nilai anti korupsi yang } \\
\text { didapat agar tercipata } \\
\text { generasi muda yang } \\
\text { berintegrasi }\end{array}$ \\
\hline $\begin{array}{c}\text { (5) } \\
\text { kegiatan akhir. }\end{array}$ & $\begin{array}{l}\text { Peneguha } \\
\text { n idea dan } \\
\text { persiapan untuk } \\
\text { mengikuti } \\
\text { pembelajaran } \\
\text { selanjutnya }\end{array}$ & $\begin{array}{l}\text { (Menempatkan } \\
\text { peranan, membuat } \\
\text { review (ulang kaji) atas } \\
\text { pembelajaran yang } \\
\text { telah dipelajari dan } \\
\text { membuat gambaran } \\
\text { pembelajaran untuk } \\
\text { masa kehadapan }\end{array}$ & $\begin{array}{l}\text { Guru menyimpulkan } \\
\text { pembelajaran hari ini dan } \\
\text { memberikan sedikit } \\
\text { gambaran tentang apa yang } \\
\text { harus disiapkan dan } \\
\text { dipelajari untuk pertemuan } \\
\text { selanjutnya }\end{array}$ \\
\hline
\end{tabular}




\section{KESIMPULAN}

Berdasarkan hasil analisis penelitian kepustakaan diketahui bahwa model Pendidikan Anti Korupsi dapat dikembangkan PAK yaitu melaui metode demokrasi, pencarian bersama, metode keteladanan, metode live in yang cocok untuk PAK untuk mengembangkan kompetensi dasar siswa agar memiliki integritas yang tinggi adalah dengan menanamkan nilai-nilai anti korupsi, sumber belajar yang cocok untuk mendukung kegiatan pembelajaran PAK adalah lingkungan alamiah dan sosial-budaya, buku-buku pelajaran dan buku teks, audio visual, dan internet adalah berupa kegiatan seperti memberikan soal tentang nilai-nilai anti korupsi perlu adanya sistem penilaian yang cocok untuk PAK untuk mengembangkan kompetensi dasar siswa adalah penilaian non tes (kinerja, sikap, portofolio, produk) dan penilaian dengan tes menggunakan model konseptual pembelajaran PAK meliputi lima tahapan yaitu: (1) kegiatan awal, (2) eksplorasi (penyelidikan dari berbagai persepktif), (3) elaborasi, 4) konfirmasi, dan (5) kegiatan akhir. Dengan demikian Pendidikan Anti Korupsi dapat dilakukan dengan cara menerapkan model Pendidikan Anti Korupsi di sekolah dasar dalam mewujudkan generasi yag bersih dan berintegritas sejak dini.

\section{SARAN}

Saran yang dapat disampaikan adalah: kegiatan ini banyak manfaatnya sehingga perlu ditindaklanjuti dan diperluas ruang lingkupnya, bila memungkinkan diadakan kerjasama dengan para stakeholder, institusi maupun pihak-pihak lain yang terkait dengan masalah ini. Misal: Komisi Pemberantasan Korupsi (KPK), dinas pendidikan, Universitas LPTK, dan lembaga-lembaga swadaya masyarakat pemerhati masalah korupsi yang ikut serta turun ke lingkungan sekolah.

\section{REFERENSI}

Asmorojati, A.W. (2017). Urgensi Pendidikan Anti Korupsi dan KPK dalam Pemberantasan Tindak Pidana Korupsi di Indonesia, Jurnal The 6th University Research Colloquium 2017 Universitas Muhammadiyah Magelang ISSN 2407-9189.

Darmawan, A.J., Bonafix, N. (2011) Perancangan Komunikasi Visual Web Games Interaktif "Gooclean.Com" Guna Menanamkan Budaya Anti Korupsi Sejak Dini, Humaniora, 2(2), 959-967.

Handoyo, E., \& Susanti, M.H. (2014). Dampak Korupsi melalui Pendidikan Anti Korupsi dalam Membentuk Generasi Muda yang Jujur dan Berintegritas di Sma Semesta Kota Semarang, Abdimas, 18(1).

Karsona, A.M., dkk. (2013). Pendidikan Anti Korupsi untuk Perguruan Tinggi. Jakarta: Kemendikbud.

Komisi Pemberantasan Korupsi. (2014). Perkembangan tindak pidana korupsi di Indonesia. Retrieved Desember 17, 2018. www.acch.kpk.go.id.

Lickona, Thomas. (1996). "Eleven Principles of Effective Character Education" dalam Journal of Moral Education. 25(1), 96. 
Manurung, R.T. (2012). Pendidikan Anti Korupsi sebagai Satuan Pembelajaran Berkarakter dan Humanistik. Jurnal Sosioteknologi Edisi 2.

Miswanto \& Badrul, M. (2016). Aplikasi Pembelajaran Anti Korupsi bagi Anak Remaja Berbasis Android, Jurnal Informatika, III(1).

Samidan P.M. (2011). Peranan Hakim dalam Penegakan Hukum Tindak Pidana Korupsi di Indonesia. Medan: Pustaka Press Bangsa.

Shobirin, M. Model Penanaman Nilai Antikorupsi di Sekolah Dasar Universitas Wahid Hasyim Semarang. Jurnal Ilmiah Pendidikan Dasar.

Siswanto, dkk. (2017). Nilai - Nilai Anti Korupsi dalam Pembelajaran Akuntansi sebagai Pengembangan Karakter Siswa di SMK , Jurnal Pembangunan Pendidikan: Fondasi dan Aplikasi, 5(1).

Tamba, M.A. (2017). Pendidikan Anti Korupsi melalui Pendidikan Kewarganegaraan, ISSN: 2598-2796 Prosiding Seminar Nasional Tahunan Fakultas Ilmu Sosial Universitas Negeri Medan Tahun 2017 Vol. 1 No. 12017. http://semnastafis.unimed.ac.id 